\title{
TOTAL LEAF AREA OF PAPAYA TREES ESTIMATED BY A NONDESTRUCTIVE METHOD
}

\author{
Robson Prucoli Posse¹; Elias Fernandes de Sousa²; Salassier Bernardo²*; Messias Gonzaga \\ Pereira $^{3}$; Romildo Domingos Gottardo ${ }^{2}$ \\ ${ }^{1}$ UENF/CCTA - Programa de Pós-Graduação em Produção Vegetal. \\ ${ }^{2}$ UENF/CCTA - Lab. de Engenharia Agrícola, Av. Alberto Lamego, 2000 - Parque Califórnia - 28013-602 - \\ Campos dos Goytacazes, RJ - Brasil. \\ ${ }^{3}$ UENF/CCTA - Lab. de Fitomelhoramento. \\ *Corresponding author <salassie@uenf.br>
}

\begin{abstract}
Leaf area estimation is an important feature in physiological research involving predominantly photosynthesis, transpiration and growth. This study was carried out to develop a practical and nondestructive empirical mathematical model to estimate the area of one leaf and the total leaf area for papaya trees (Carica papaya L.). Two irrigated commercial orchards were evaluated over a period of 50 to 550 days after transplanting, during which the length of the leaf midrib (LM) varied from 0.04 to $0.60 \mathrm{~m}$. A mathematical model was developed to estimate the area of one leaf for the papaya tree, taking into account LM and the age of the plant measured in days after transplanting. The model was considered satisfactory. Based on the average length of the last two leaves of the crown and the total leaf number of the plant, it was possible to satisfactorily estimate the total leaf area of the papaya tree.
\end{abstract}

Key words: Carica papaya L., papaya, model, leaf architecture, biometry

\section{ÁREAFOLIARTOTALDOMAMOEIRO ESTIMADA POR UM MÉTODO NÃO-DESTRUTIVO}

\begin{abstract}
RESUMO: A estimativa da área foliar é importante no estudo de aspectos fisiológicos que envolvam, principalmente, crescimento, transpiração e fotossíntese. Desenvolveu-se um modelo matemático empírico prático e não-destrutivo para estimativa da área de uma folha e a área foliar total do mamoeiro (Carica papaya L.) em pomar comercial. Para isso foram avaliados dois pomares irrigados. As plantas foram avaliadas no período de 50 a 550 dias após o transplantio, em que as folhas tiveram o comprimento da nervura central (LM) variando de 0,04 m a 0,60 m. Um modelo matemático foi desenvolvido para a estimativa da área de uma folha do mamoeiro, levando em consideração o LM e a idade da planta, representada em dias após o transplantio. O modelo foi considerado satisfatório. Com base no comprimento médio das duas ultimas folhas da copa e do número total de folhas presentes na planta pode-se estimar a área foliar total do mamoeiro.

Palavras-chave: Carica papaya L., mamão, modelo, arquitetura foliar, biometria
\end{abstract}

\section{INTRODUCTION}

The adequate management of crops depends on the knowledge of the plant water demand for a successful irrigation and optimization of the available water resources. But, the nutrition of the plants, the control of pests and diseases, as well as the choice of productive varieties should be appropriately optimized in order to reach the potential production of the crop under irrigation.

Papaya tree is a very sensitive plant to either water deficit (Aiyelaagbe et al., 1986; Bernardo et al., 1996) and to wetting (Marin et al., 1995; Coelho et al., 1999). So, the monitoring of the soil moisture or of the water volume of soil to be restored on the ba- sis of water consumption is essential for a satisfactory development of the crop.

In estimating transpiration, the leaf area has been successfully taken as a criterion for several crops (Coelho Filho et al., 2004; Villa Nova et al., 2002; David et al., 2002). Together with crown architecture and planting arrangement within the orchard, these biological factors are determinant for the interception of the light energy, therefore for the efficiencies of both photosynthetic and respiratory rates (Pereira et al., 1997; Nobel, 1991; Taiz \& Zeiger, 1991). Because the leaf is the main organ responsible for the transpiration process (Pereira et al., 1997), the knowledge about the leaf area is important for evaluating and following the vegetal growth and water loss by the plant (Norman \& Campbell, 1989). 
One of the main problems in estimating the total transpiration of the plant is the difficulty of determining the leaf area in an accurate and nondestructive way, in order to monitor plant growth continuously on the same plant. For the measurement of plant leaf area, either direct or indirect methods can be used, and this choice will depend on the objective of the study to be accomplished, the sample size, the leaf morphology, the time dedicated to this evaluation, among others. The direct method is destructive because it consists in the removal and measurement of the leaves, besides requiring adequate equipment which sometimes is costly. The indirect methods are used for the nondestructive evaluation of an estimate of the total leaf area or of one leaf (Norman \& Campbell, 1989).

Several mathematical models were developed for the indirect measurement, most of them using relationships between dimensions of the leaves and the total leaf area. Among the various indirect methods available for the determination of leaf area, each with its specific mathematical model and measuring technique depending on the architecture of the leaf, one that can be highlighted is that of Sousa et al. (2005) for coconut, that of Coelho Filho et al. (2005a) for the acid lime 'Tahiti', both of which determine the area of only one leaf to calculate the total leaf area of the plant, and the model of Araújo et al. (2005) which also determines the area of only one leaf of the mango tree.

This study was carried out to develop a practical and nondestructive empirical mathematical model to estimate the area of one leaf and the total leaf area for papaya trees (Carica papaya L.).

\section{MATERIALAND METHODS}

At the first stage of this study, an empirical model was developed to estimate the area of one leaf of a papaya tree. Leaves were collected during random periods at several days after transplanting (DAT) from the nursery, belonging to two papaya tree orchards under irrigation. One orchard was composed of the Hybrid UENF/CALIMAN01 cv. of the 'Formosa' group, in Campos dos Goytacazes, Rio de Janeiro state

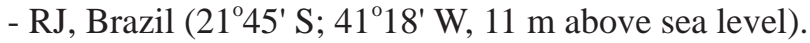
Seedlings of these trees were transplanted to the field on 04/25/2006 (0 DAT), and their leaves were evaluated until $05 / 18 / 2007$, at the following dates 50; 62; 71; 84; 317; 388 DAT. The second orchard was composed of two cultivars: hybrid UENF/CALIMAN01 and Golden of the 'Solo' group, in Itaocara, RJ, Brazil (213' S; 4203' W, $60 \mathrm{~m}$ above sea level). In this orchard, the transplant of the seedlings to the field was made on 05/05/2006. On 11/06/2007 (550 DAT), 40 leaves were collected and evaluated, 20 from each cultivar. From both orchards, a total of 763 leaves was collected and evaluated at different periods. On each collected leaf the length of the midrib (LM) was measured with a graduated ruler of millimeter precision, and the value of the leaf area was obtained with a leaf area meter (LI-3100 Area meter, LI-COR inc., Lincoln, Nebraska, USES). The length of the midrib of these leaves varied from $0.04 \mathrm{~m}$ to $0.60 \mathrm{~m}$.

The different coefficients found by several authors (Alves \& Santos, 2002; Campostrini \& Yamanishi, 2001; Coelho Filho et al., 2005b) for the estimation of the leaf area of papaya trees apparently show the influence of the age of the plant under evaluation. The introduction of the variable DAT into the model of leaf area estimation (Equation 1) turns the estimate of the leaf area more accurate along the crop cycle.

After looking at the measurements, a potential model for estimating the leaf area of the papaya tree (Equation 1) was adjusted by linear regression under the anamorphosis scheme, by using the length of the midrib (LM) as independent variable and the age of the plant in DAT (in day):

$L A=\left[a \times L M^{(b \ln D A T+c)}\right] \times 10^{-4}$

where: $L A$ - leaf area $\left(\mathrm{m}^{2}\right) ; L M$ - length of the midrib (cm); and $a, b$ and $c$ - estimated regression coefficients.

A model taking into account only the midrib ( $\mathrm{LA}_{\mathrm{CY}}$, in $\mathrm{m}^{2}$ ) was found by Campostrini \& Yamanishi (2001) in four papaya tree genotypes, using two of the group 'Solo' (Sunrise Solo and Improved Sunrise Solo 72/ 12) and two of the group 'Formosa' (Tainung 02 and Known-You 01). The model (equation 2) found by these authors was adjusted for the lengths of the midribs within the interval from $0.25 \mathrm{~m}$ to $0.60 \mathrm{~m}$, in plants at age of 150 to 180 DAT.

$\left.L A_{C Y}=10^{(0.315+1.85 \times \log L M)}\right] \times 10^{-4}$

After the mathematical model described by eq. 1 was defined, the second experimental stage was to verify if the models were statistically similar for the average age (165 DAT) of the plants evaluated by Campostrini \& Yamanishi (2001).

The total leaf area can be estimated by measuring the length of all midribs of one tree and summing the areas of all leaves. However, this procedure is laborious and expensive, becoming rather unviable. Therefore, the third experimental stage was to develop a model to estimate the total leaf area using the minimum number of variables as possible.

From the orchard placed in Itaocara, RJ, 90 plants had their leaves removed in decreasing positional order (location) in the plant, from the older to the younger 
leaves. The leaf with the length of the midrib higher or equal to $0.04 \mathrm{~m}$ was considered as number one. According to the architecture of each plant, LM was measured for all leaves. Then, the leaf-area estimation model (eq. 1) was used to determine the total leaf area, by summing the areas of all leaves. The total leaf numbers ( $\mathrm{LN}$ ) and the average length of the midrib of the last two leaves in the crown (AL2, cm) were also estimated.

Using multiple linear regression an empirical model for the estimation of the total leaf area (TLA, $\mathrm{m}^{2}$ ) was adjusted by the following equation:

$$
\begin{aligned}
& \mathrm{TLA}=\left[-\mathrm{a}_{1}+\left(\mathrm{b}_{1} \times \mathrm{LN}\right)+\left(\mathrm{c}_{1} \times \mathrm{LN} \times \mathrm{AL} 2\right)+\right. \\
& \left.\left(\mathrm{d}_{1} \times \mathrm{AL} 2\right)\right]^{1_{1}} \times 10^{-4}
\end{aligned}
$$

where: $\mathrm{a}_{1}, \mathrm{~b}_{1}, \mathrm{c}_{1}, \mathrm{~d}_{1}$ and $\mathrm{e}_{1}$ are estimated regression coefficients.

To validate the model (Equation 03), 20 plants from the Itaocara Experimental Field, ten of the Golden cv. and ten of the Hybrid UENF/CALIMAN01 were evaluated. Measurements of the lengths of the midrib were accomplished in all leaves.

The validation of the models was made adjusting the simple linear regression model of the predicted values (dependent variable) to the respective observed values (independent variable). The statistical analyses were conducted under the hypotheses:

$$
\left\{\begin{array} { l } 
{ H _ { 0 } : \beta _ { 0 } = 0 } \\
{ H _ { a } : \beta _ { 0 } \neq 0 }
\end{array} \quad \left\{\begin{array}{l}
H_{0}: \beta_{1}=1 \\
H_{a}: \beta_{1} \neq 1
\end{array}\right.\right.
$$

where: $\beta_{0}$ and $\beta_{1}$-intercept and slope of the adjusted straight line between the observed and estimated data, respectively.

In the case both hypotheses are not rejected, it was concluded that the equivalence occurred between the predicted and observed values. The value 0.01 was adopted as the critical probability level for the occurrence of the type-I error.

\section{RESULTS AND DISCUSSION}

The measured and the simulated values were not different. This model (eq. 1) was significant by regression analysis $\left(p<0.01, \mathrm{R}^{2}=0.99\right.$ and root mean squared error $(\mathrm{RMSE})=0.014 \mathrm{~m}^{2}$ - Figure 1$)$.

In all studies presenting models for the estimation of the leaf area of papaya trees, the use of the length of the midrib only indicated that the method is simple and accurate but exclusive for the sampling date or for the age of the plant under evaluation. The use of one model only to estimate the leaf area of the papaya tree in both groups 'Solo' and 'Formosa' (Campostrini
\& Yamanishi, 2001; Alves \& Santos, 2002) demonstrates the potential of a model generated in one cultivar for the other, regardless of the group or genotype.

The model proposed by Campostrini \& Yamanishi (2001) presents coefficients for the plants within 150 to 180 DAT. When the average age of the plant under evaluation was used by the authors (165 DAT) in eq. 1 , and an estimate is performed for different lengths of the midrib, varying from 0.25 to $0.60 \mathrm{~m}$ according to the extent of the model proposed by Campostrini \& Yamanishi (2001), an adjustment between the models was observed, not differing from each other $(p<$ 0.01 , RMSE $=0.017 \mathrm{~m}^{2}$ - Figure 2), demonstrating that both models did not differ from each other for the considered period of DAT (150-180). These results

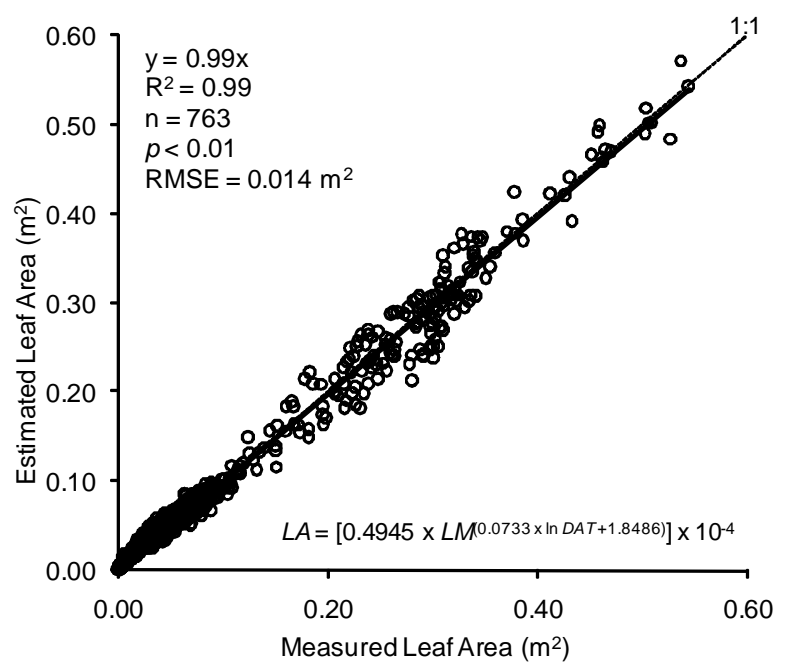

Figure 1 - Relationship between leaf area measured by the LI3100 meter and the leaf area estimated by the model (Eq. 1). (RMSE = root mean squared error).

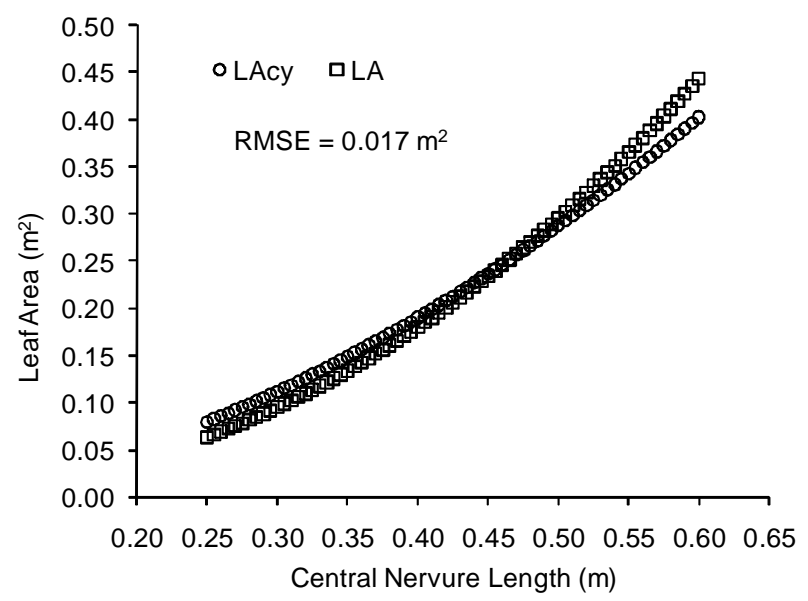

Figure 2 - Estimate of the leaf area (LA) with either the method by Campostrini \& Yamanishi (2001) $\left(\mathrm{LA}_{\mathrm{CY}}\right.$ ) for leaves from 0.25 to $0.60 \mathrm{~m}$ or the model of Equation 1 (LA) for leaves from 0.25 to $0.60 \mathrm{~m}$ at 165 DAT (days after transplanting). 
indicate the viability of estimating quickly and with satisfactory accuracy the leaf area of papaya trees, using the simple measure of the length of the midrib at any development age of the plant.

It was possible to adjust a model for the determination of the total leaf area (Equation 03), turning the estimate of the total leaf area of the papaya tree simple and accurate, since just using AL2 and LN it is possible to determine TLA. This model was significant $\left(p<0.01, R^{2}=0.99\right.$, Figure 3).

In validating the model with the 20 plants, ten of the cultivar Hybrid UENF/CALIMAN01 and ten of the Golden cv., a correspondence between the generated model and the total real leaf area was observed. No differences occurred between both cultivars, when determining the leaf area, so corroborating the results previously presented by Campostrini \& Yamanishi (2001) and by Alves \& Santos (2002), for which a single model can be representative for any cultivar.

In the validation of the model, Figure 4 expresses the relationship between the observed values of the total leaf area and those predicted by this model. The statistical evaluation of the model expressing the relationship among the data groups rather indicated the equivalence between the predicted and observed values, according to the hypotheses in (eq. 4). The model was significant $\left(p<0.01, \mathrm{R}^{2}=0.98\right.$, RMSE $=0.44 \mathrm{~m}^{2}$, Figure 4 ). The value of RMSE is less than the area of one leaf. With the obtained model, the abacus shown in Figure 5 was constructed. With this abacus it is easy to obtain the estimated value of the total leaf area of the papaya tree as a function of AL2 and LN.

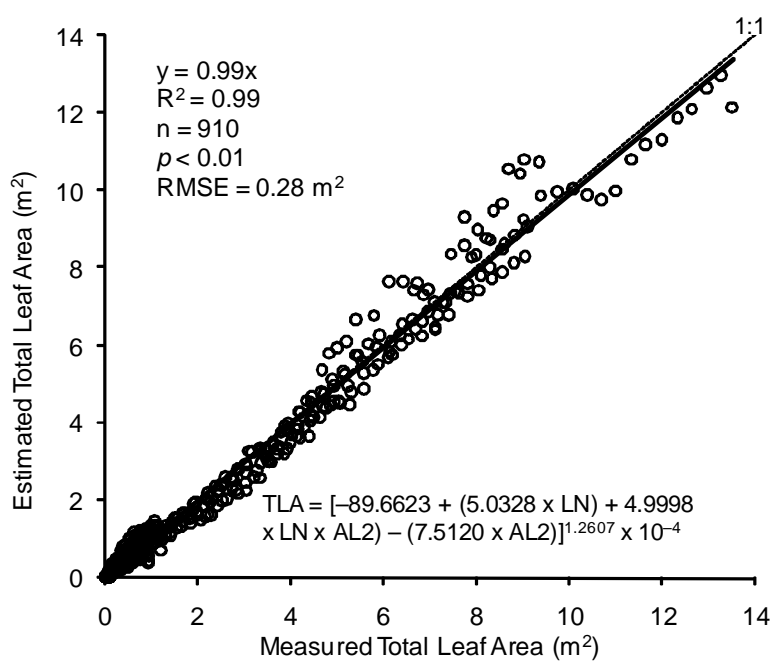

Figure 3 - Relationship between the total leaf areas of irrigated papaya trees estimated by the model and measured values. $(\mathrm{RMSE}=$ root mean squared error).

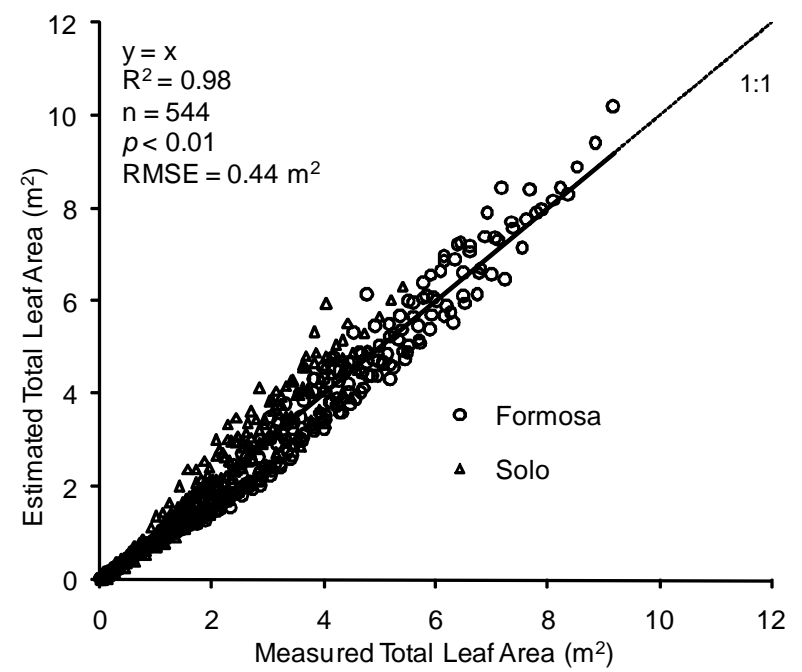

Figure 4 - Correspondence between measured values of the total leaf area and the values estimated by the model for papaya trees of the group 'Solo' and 'Formosa', grown in Rio de Janeiro state, Brazil. (RMSE = root mean squared error).

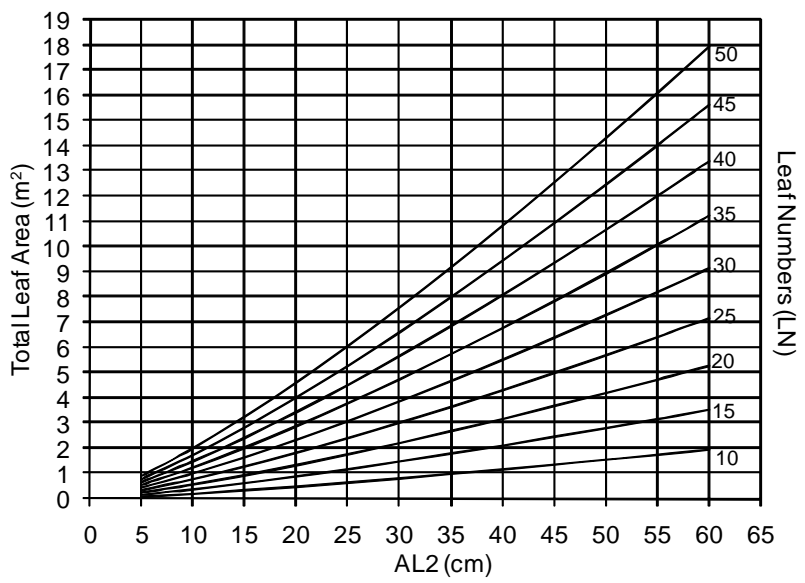

Figure 5 - Abacus to estimate the total leaf area of papaya trees from the average length of the last two leaves in the crown (AL2) and of the total leaf numbers of the crown $(\mathrm{LN})$.

\section{ACKNOWLEDGEMENTS}

To CAPES, FAPERJ, CNPq and FINEP for financial support.

\section{REFERENCES}

AIYELAAGBE, I.O.O; FAWSI, M.O.A.; BABALOLA, O. Growth, development and yield of pawpaw (Carica papaya L.) 'Homestead selection' in response to soil moisture stress. Plant and Soil, v.93, p.427-435, 1986.

ALVES, A.A.C.; SANTOS, E.L. Estimativa da área foliar do mamoeiro utilizando medidas da folha. In: CONGRESSO BRASILEIRO DE FRUTICULTURA, 17., Belém, 2002. Anais. Belém: CBF, 2002. Available at: http://www.ufpel.tche.br/sbfruti/ anais_xvii_cbf/fisiologia/567.htm. Accessed 28 Aug. 2006. 
ARAÚJO, E.C.E.; SANTOS, E.P.; PRADO, C.H.B.A. Estimativa da área foliar da mangueira (Mangifera indica L.) cvs. Tommy atkins e haden, utilizando dimensões lineares. Revista Brasileira de Fruticultura, v.27, p.308-309, 2005.

BERNARDO, S.; CARVALHO, J.A.; SOUSA, E.F. Irrigação do mamoeiro. Campos dos Goytacazes: UENF, 1996. 20p. (Boletim Técnico, 5)

CAMPOSTRINI, E.; YAMANISHI, O.K. Estimation of papaya leaf area using the central vein length. Scientia Agricola, v.58, p.39-42, 2001.

COELHO, E.F.; SILVA, J.G.F.; SOUZA, L.F.S. Irrigação e fertirrigação. In: SANCHES, N.F.; DANTAS, J.L.L. (Coord.) O cultivo do mamão. Cruz das Almas: Embrapa Mandioca e Fruticultura, 1999. cap.7, p.32-41. (Circular Técnica, 34).

COELHO FILHO, M.A.; ANGELOCCI, L.R.; ROJAS, J.S.D.; CAMPECHE, L.F.S.M.; FOLEGATTI, M.V. Relações entre transpiração máxima, área foliar e evapotranspiração de referência em pomar jovem de lima ácida 'tahiti'. Revista Brasileira de Agrometeorologia, v.12, p.265-274, 2004.

COELHO FILHO, M.A.; ANGELOCCI, L.R.; VASCONCELOS, M.R.B.; COELHO, E.F. Estimativa da área foliar de plantas de lima ácida 'tahiti' usando métodos não-destrutivos. Revista Brasileira de Fruticultura, v.27, p.163-167, 2005a.

COELHO FILHO, M.A.; COELHO, E.F.; ALVES, A.A.C. Método para estimativa da área foliar de plantas de mamoeiro do grupo solo e formosa. In: MARTINS, D.S. (Ed.) Papaya Brasil: mercado e inovações tecnológicas para o mamão. Vitória: INCAPER, p.525-528, 2005b.

DAVID, T.S.; FERREIRA, I.; PEREIRA, J.S.; COHEN, S.; DAVID, J.S. Transpiração em árvores isoladas de um montado de azinho, evolução sazonal e condicionantes hidráulicas. Silva Lusitana, v.10, p.133-149, 2002.
MARIN, S.L.D.; GOMES, J.A.; SALGADO, J.S.; MARTINS, D.S.; FULLIN, E.A. Recomendações para a cultura do mamoeiro dos grupos solo e formosa no Estado do Espírito Santo. 4 ed. Vitória: EMCAPA, 1995. 57p. (Circular Técnica, 3)

NOBEL, P.S. Physicochemical and environmental plant physiology. San Diego: Academic Press, 1991. 635p.

NORMAN, J.M.; CAMPBELL, G.S. Crop structure. In: PEARCY, R.W.; EHLERINGER, J.R.; MOONEY, H.A.; RUNDEL, P.W. Plant physiological ecology: field methods and instrumentation. New York: Chapman and Hall, 1989. p.457.

PEREIRA, A.R.; VILLA NOVA, N.A.; SEDIYAMA, G.C. Evapo(transpi)ração. Piracicaba: FEALQ. 1997. 183p.

SOUSA, E.F.; ARAÚJO, M.C.; POSSE, R.P.; DETMANN, E.; BERNARDO, S.; BERBERT, P.A.; SANTOS, P.A. Estimating the total leaf área of the green dwarf coconut tree (Cocos nucifera L.). Scientia Agricola, v.62, p.597-600, 2005.

TAIZ, L.; ZEIGER, E. Plant physiology. Redwood City: Benjamin/ Cummings, 1991. 559p.

VILLA NOVA, N.A.; ANGELOCCI, L.R.; VALANCOGNE, C.; SENTELHAS, P.C.; PEREIRA, A.R.; MARIN, F.R. Estimativa da transpiração máxima de macieiras, em pomares irrigados, pelo método de Penman adaptado. Revista Brasileira de Agrometeorologia, v.10, p.245-250, 2002.

Received December 18, 2007 Accepted February 17, 2009 